\title{
SEASONAL DISTRIBUTION OF ROTIFER DIVERSITY IN SELECTED FISH PONDS AND MARALA HEADWORKS SIALKOT, PAKISTAN
}

\author{
G. Dastgeer ${ }^{1}$ M. Hussain ${ }^{* 1}$, K. Aftab ${ }^{1}$, M.S. Tufail ${ }^{2}$, M.F. Malik ${ }^{1}$, M. Umar ${ }^{1}$ and M.S. Sajid ${ }^{1}$ \\ ${ }^{1}$ Department of Zoology, University of Gujrat, Punjab, Pakistan \\ ${ }^{2}$ Department of Zoology, Government College University Lahore, Punjab, Pakistan \\ *Corresponding author's email: dr.mubashar@uog.edu.pk
}

\begin{abstract}
Seasonal distribution and diversity of Rotifers was explored at Marala Headwork (Lake) and selected fish ponds of district Sialkot, Punjab, Pakistan. Samples were collected randomly from the selected sites in the morning (09 am-11am) with the help of zooplankton net during different seasons in 2017-2018. Rotifers counting was accomplished by Sedgewick-Rafter chamber under a compound microscope. We recorded fourteen species, 09 genera and 04 families at Marala Lake whereas 07 species, 05 genera and 06 families in fish ponds. B. angularis, B. calyciflorus, F. minuta, $K$. cochlaeris, $K$. valga, L. lunaris and P. roseola were common species recorded at both habitat types. Brachionidae was the most prevalent family throughout the year at both habitat types. Data recorded showed variations in the temperature $\left(21{ }^{\circ} \mathrm{C}-32.8{ }^{\circ} \mathrm{C}\right.$ in Fish Ponds and $19.3{ }^{\circ} \mathrm{C}-28.1{ }^{\circ} \mathrm{C}$ in Marala Lake), the gravity in fish ponds and Marala Lake varied from 1.001 to 1.003 , electrical conductivity $(317 \mu \mathrm{s} / \mathrm{cm}$ to $396 \mu \mathrm{s} / \mathrm{cm}$ in fish ponds and $259 \mu \mathrm{s} / \mathrm{cm}$ to $315 \mu \mathrm{s} / \mathrm{cm}$ in Marala Lake) and pH (6.7 to 9.2 in fish ponds and 6.5 to 9.06 at Marala Lake). Significantly different diversity (p $\leq 0.05)$ was recorded in fish ponds and Marala lake during different seasons i.e. autumn (H: 1.90 and H: 2.46), winter (H: 1.61 and $\mathrm{H}: 2.01)$ spring (H: 1.90 and $\mathrm{H}: 2.50)$ and summer $(\mathrm{H}: 1.91$ and $\mathrm{H}: 2.52)$. Diversity indices showed higher population diversity of rotifers in Marala Lake than fish ponds. The study emphasized that natural bodies need to be explored extensively for the biodiversity of rotifers with special reference to physiochemical parameters for their conservation.
\end{abstract}

Keywords: Population dynamics, physico-chemical parameters, rotifers diversity.

https://doi.org/10.36899/JAPS.2020.5.0148

Published online June 25, 2020

\section{INTRODUCTION}

Rotifers are represented by 03 classes, 120 genera and 2150 species (Barnes et al. 2009) which were reported from almost in all types of freshwater habitat (Wallace and Smith 2013; Lubzens et al. 2001). They have ability to adapt and tolerate adverse environment under different types of ecological conditions (Neves et al. 2003). Rotifers have higher population density and diversity among zooplankton of freshwater bodies (Kar and Kar 2016). In lakes rotifers often achieve high population densities i.e. $>1000$ individuals per litre.

Rotifers as consumers of bacteria, algae and protists have great ecological importance in energy transfer (Wallace and Smith 2013). Rotifers serve as food for young fishes, contribute significantly in commercial aquaculture and serve as models for research on ageing, and as bioindicators for ecotoxicology (Baloch et al. 2005; Wallace et al. 2006; Wallace and Smith 2013; Chieng et al. 2018). Rotifers play a significant role in fish culture and give a clear indication to determine quality of water and eutrophication (Saler 2009). Among the planktons, rotifers are very important metazoans due to their role as key indicators of eutrophication (Skowronek et al. 2012; Bhandarkar 2015). Physico-chemical parameters and biological characteristics of water have a significant role in productivity of planktons and aquaculture products (Dhanasekaran et al. 2017). The physico-chemical and biological characteristics of water reservoirs detemine the water quality and distribution of living organisms. Physico-chemical parameters of an ecosystem have more obvious influence on the composition and distribution of zooplankton (Papa and Zafaralla 2011; Kumar and Kiran 2015). Factors including physico-chemical parameters, competitors, predators and food resources have a direct effect on population dynamics of rotifers (Sugumaran and Amsath 2015).

Seasonal occurrence of rotifers and their relation with physico-chemical parameters of water bodies i.e. temperature, salinity and primary productivity, etc. has been studied from different aquatic ecosystems (Sharma 2000; Saler and Sen 2002) including Pakistan (Mahar et al. 2000; Baloch et al. 2004; Malik and Sulehria 2004; Baloch et al. 2008). Temperature, nutrients, food resources, competitors and predators are the major factors that affect the community structure of rotifers (Sulehria and Malik 2012; Ekhande et al. 2013). Rotifer density and diversity has been found positively 
correlated with temperature, electrical conductivity and $\mathrm{pH}$ whereas negative correlation of dissolved oxygen.

The survival and reproductive rate of rotifers depends on the abundance of food and temperature; and the life cycle of rotifers is extremely short during favorable conditions such as high temperature, photoperiod and availability of food (Sugumaran and Amsath 2015; Rajendiran and Subramanian, 2007; Yoshinaga et al. 2003; Kirk 1997). The reproductive rate of rotifers is greatly affected by seasonal fluctuations in temperature. Population decline results due to increased mortality under imbalance predatory action (Gunwati and Mokashe 2014). The water exchange is very slow in standing water; therefore, pollutants, toxins, nutrients and fertilizers can change the water quality with the passage of time. The cultural eutrophication resulted in increased density of rotifers in pond (Bhandarkar 2015).

The seasonal fluctuations have significant impact on population dynamics of rotifers under different habitats i.e. natural reservoirs and fish ponds. The present study was designed to explore the diversity of rotifers in Marala Lake and fish ponds in association with the physico-chemical parameters during different seasons. The study has not only documented the diversity of rotifers at Marala Lake and selected fish ponds but also provided an insight into the water quality of these reservoirs.

\section{MATERIALS AND METHODS}

Locations and sampling: Sialkot $\left(32^{\circ} 29^{\prime} 33^{\prime \prime} \mathrm{N}\right.$, $\left.74^{\circ} 31^{\prime} 52^{\prime \prime} \mathrm{E}\right)$ is in the north-east of the Punjab near the Chenab River which flows at north of Sialkot. Marala Lake and selected fish ponds in Punjab Fisheries Department at Kotli Araian, Marala road, Sialkot were sampled during 2017-2018 from the selected sites between 9 am to $11 \mathrm{am}$. Sampling was conducted during different seasons i.e. winter (December-February), spring (March-April), summer (May-June), Monsoon (JulySeptember) and autumn (October-November) (Zahid and
Rasul 2011). Three sites were selected at Marala Lake which were further subdivided into three locations (Figure 1). The sampling was carried out from three fish ponds with area of each pond was 4 kanals and with a depth of 8 feet. Zooplankton net with a mesh size of 37 $\mu \mathrm{m}$ was used for sampling.

Sampling of water and rotifers: Water samples were taken in the Van Dorn bottle which were soaked in $2.5 \%$ dilute $\mathrm{HCl}$ solution. Distilled water was used for washing the sample bottles ( 2 to 3 times). Water and air temperature $\left({ }^{\circ} \mathrm{C}\right)$, DO $(\mathrm{mg} / \mathrm{L}), \mathrm{EC}(\mu \mathrm{s} / \mathrm{cm})$, TDS $(\mathrm{ppm})$ and $\mathrm{pH}$ were measured with thermometer, Oxygen meter, conductivity meter, TDS meter and $\mathrm{pH}$ meter, respectively (APHA 2005 ). Rotifer samples were preserved in $4 \%$ formalin in small plastic Nalgene bottles (Sulehria and Malik 2012). Some samples were kept without formalin to study the live organisms.

Identification and counting of rotifers: Magnus Trinocular compound microscope (Model-MLX TR) was used to examine the samples of rotifers. Trinocular compound microscope having a 5.0 megapixel camera was used to take images of rotifers. Live rotifers were observed and stained with vital stain ( $1 \%$ neutral red) for observing internal features. Identification of rotifers up to species level was carried out based on their body shape and morphology (Ward and Whipple 1959; Pennak 1989; Segers 2007). Sedgewick-Rafter chamber was used for the counting of rotifers under a compound microscope, filled with sample and covered with cover slip. The counting was started, when sample was settled after 2 to 4 minutes (APHA 2005).

Density of rotifers (number $/ \mathrm{ml}$ ) $=\mathrm{C} \times 1000$ $\mathrm{mm} / \mathrm{L} \times \mathrm{D} \times \mathrm{W} \times \mathrm{S}$

Diversity indices of rotifers: The diversity of rotifer species and relative abundance were calculated through Shannon-Wiener index (Shannon and Weaver 1949) and Simpson's Index (Simpson 1949). 


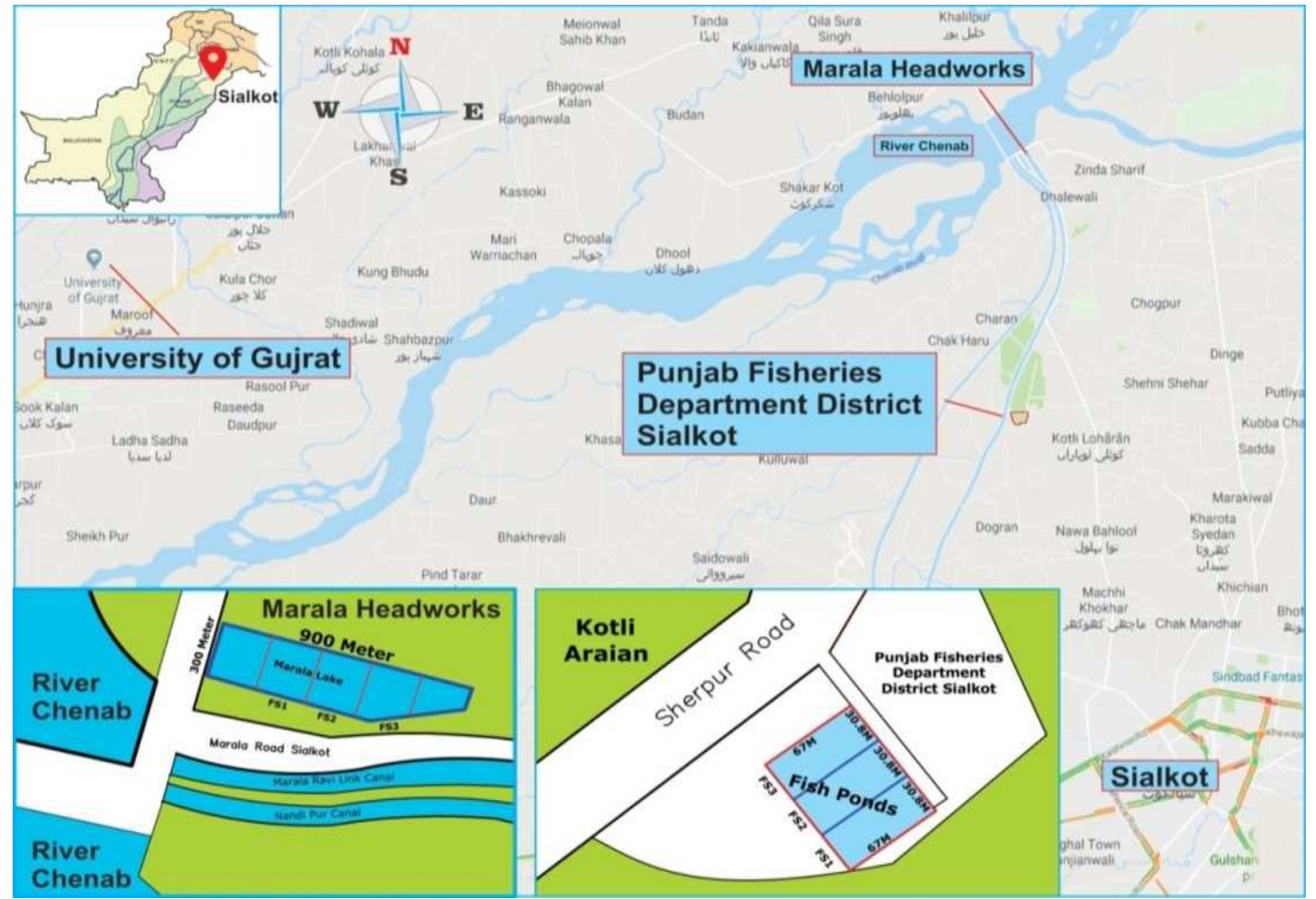

Figure 1. Map of Marala headwork and Punjab fisheries departments in district Sialkot, Punjab, Pakistan.

Statistical analysis: Data were subjected to analysis by using MINITAB Software, version 13. Pearson's correlation was performed to assess the relationships between the rotifer species and various physico-chemical parameters (Schober et al. 2018). Analysis of Variance (ANOVA) was applied to determine the significance level $(\mathrm{p} \leq 0.05)$ of mean values of rotifer diversity, density and abundance during different seasons (Sulehria and Malik 2012).

\section{RESULTS AND DISCUSSION}

We reported fourteen species and 09 genera belonging to 06 families from Marala Lake whereas 07 species representing 05 genera and belonging to 04 families were recorded from fish ponds. The most abundant family was Brachionidae in both habitat types. We also noted water quality parameters in different seasons. Seasonal variations in the water quality parameters (water and air temperature $\left({ }^{\circ} \mathrm{C}\right), \mathrm{DO}(\mathrm{mg} / \mathrm{L}), \mathrm{EC}(\mu \mathrm{s} / \mathrm{cm})$, TDS $(\mathrm{ppm})$ and $\mathrm{pH}$ indicated significant differences $(\mathrm{p} \leq 0.05)$. Mean values of specific gravity at both sites, however, showed non-significant results $(\mathrm{p}>0.05)$. Diversity indices also recorded changes in the species dominance, richness, and evenness with respect to different seasons.
Physico-chemical parameters: Significant variations ( $p$ $\leq 0.05$ ) were observed in physico-chemical parameters at both habitats i.e. dissolved oxygen, water temperature, specific gravity and electrical conductivity (Table $1 \& 2$ ). At both sites, ANOVA results indicated that mean values of air and water temperatures, dissolved oxygen, electrical conductivity, $\mathrm{pH}$ and total dissolved solids were significant $(\mathrm{p} \leq 0.05)$ during different seasons. Temperature varied from $21^{\circ} \mathrm{C}-32.8^{\circ} \mathrm{C}$ in Fish Ponds and $19.3{ }^{\circ} \mathrm{C}-28.1{ }^{\circ} \mathrm{C}$ in Marala Lake. The specific gravity in the fish ponds and Marala Lake varied from 1.001 to 1.003 . Electrical conductivity varied from 317 $\mu \mathrm{s} / \mathrm{cm}$ to $396 \mu \mathrm{s} / \mathrm{cm}$ in the fish ponds and $259 \mu \mathrm{s} / \mathrm{cm}$ to $315 \mu \mathrm{s} / \mathrm{cm}$ in Marala Lake. The $\mathrm{pH}$ varied from 6.7 to 9.2 in fish ponds. TDS concentration varied from $160 \mathrm{ppm}$ to $194 \mathrm{ppm}$ in fish ponds and $131 \mathrm{ppm}$ to $151 \mathrm{ppm}$ in Marala Lake. Lower values of TDS were recorded in fish ponds as compared to Marala Lake.

Correlation of Physico-chemical Parameters and Rotifers density: Dissolved oxygen also showed strong positive correlation with population dynamics of rotifers at both habitat types i.e. Marala Lake and fish ponds. Electrical conductivity showed strong negative correlation with rotifer population. 
Diversity and density of rotifers in selected ponds and Marala Lake was explored and correlated with physico-chemical parameters of these water reservoirs (Table 3 \& 4). Results also displayed significant variations $(\mathrm{p} \leq 0.05)$ for seasons, sites and season $\mathrm{x}$ site interactions for physicochemical parameters except specific gravity (Table 5). Overall abundance and number of species from different sites during different seasons were also subjected to two-way ANOVA, the results exhibited significant differences in overall specimen abundance $\left(\mathrm{F}_{(1,16)}=66.10, \mathrm{p}=0.0000\right)$ and number of species $\left.\mathrm{F}_{(1,16)}=60.17, \mathrm{p}=0.0000\right)$.

Diversity and density of rotifers: In fish ponds, seven species were recorded from winter, summer and spring (each season) while five species were recorded in autumn. In fish ponds, 07 species representing 05 genera and 04 families were reported (Figure 2). The greater population abundance was recorded for Brachionus angularis $(21.68 \%)$ whereas the lowest population abundance for Lecane lunaris (9.79\%).

Fourteen species in autumn, summer and spring (each season) whereas twelve species were recorded in winter at Marala Lake. The diversity and abundance of rotifers at Marala Lake showed the presence of fourteen species and 09 genera belonging to 06 families. Population abundance recorded from Marala Lake showed that Brachionus falcatus (10.42\%) and Keratella cochlaeris $(10.42 \%)$ were the most abundant species whereas Lecane lunaris (1.49\%) was the least abundant species (Figure 3).

Greater abundance of rotifer species was recorded in summer $(19.33 \pm 0.67$ individual $/ \mathrm{ml})$ and the lowest abundance was observed in winter $(5.67 \pm 0.88$ individual $/ \mathrm{ml}$ ) in fish ponds (Figure 4). Brachionidae $(61.55 \%)$ was the most abundant family whereas the least abundant family noted was Philodinidae (12.59\%). Greater rotifer population was observed in summer season (47.0 individual $/ \mathrm{ml}$ ) and the lowest was in winter (11.33 individual $/ \mathrm{ml}$ ). The highest percentage of family Brachionidae (58.04\%) and the lowest percentage of family Lecanidae (1.49\%) was observed during the rotifer sampling from Marala Lake and fish ponds, respectively. Diversity indices were measured on seasonal basis which showed that the value of Shannon-Wiener Index was lower in winter (1.611) and higher in summer (1.915) at fish ponds (Table $6 \& 7$ ). Mean values of diversity indices were also subjected to ANOVA test for finding significance level, the results showed significant differences in Shannon-Wiener index $\left(\mathrm{F}_{(1,3)}=125.9, \mathrm{p}=\right.$ $0.0015)$ and species richness $\left.\mathrm{F}_{(1,16)}=23.89, \mathrm{p}=0.0164\right)$. However, species evenness showed significant difference among seasons $\left(\mathrm{F}_{(3,3)}=22.10, \mathrm{p}=0.0151\right)$ but were found non-significant in sites $(\mathrm{p}>0.05)$.

Our results suggest that seasons have strongly affected rotifer density, species abundance, richness and evenness. These variations were strongly correlated with physico-chemical parameters either positively or negatively. Availability of resources, competition, disturbances and environmental changes influence local community structure and diversity (Cottenie and Meester 2004). In our study, local processes might be responsible for the variations in the species composition, abundance and density (Allen et al. 2011). The family Brachionidae was the most abundant and frequent taxa in our study with predominance of the Brachionus genus. This trend has not only been documented in our study but also in other studied conducted in freshwater ecosystems of the subcontinent. B. angularis, B. calyciflorus, $F$. minuta, $K$. cochlaeris, $K$. valga, L. lunaris and P. roseola were other important species reported from both habitat types. These genera were also reported from other locations during different seasons (Ejaz et al. 2016; Hussain et al. 2016; Sugumaran and Amsath 2015; Sulehria et al. 2009b).

Twenty eight rotifer species were reported from planktonic rotifers of Nandipur Canal (Ejaz et al. 2016), 101 species belonging to thirty two genera in the Floodplain of River Ravi (Hussain et al. 2016), 10 species of rotifers belonging to 7 genera from Bhawalnagar (Sulehria et al. 2009a), sixteen rotifer species belonging to eleven genera from Mianwali (Sulehria et al. 2009b). Similar results were observed from other studies where most abundant species included Brachionus caudatus, B. falcatus, $H$. thomassoni, $F$. longiseta, $C$. dossuarius, and $K$. cochlearis (VázquezSánchez et al. 2014). Brachionidae was dominated rotifer family with respect to species composition as well as species abundance (Sharma et al. 2013). Similar results were reported in other studies reporting that increase in the temperature proportionately increases the rate of growth of rotifer population (Baloch et al. 2008; Sulehria et al. 2009 a,b; Sulehria and Malik 2012). Decreased competition due to increased food resources and improved water quality resulted in increased diversity of rotifers (Thomaz et al. 2007).

We reported that genus Brachionus was the dominant species representing the Brachionidae family during all seasons. Similar results were reported in various studies reporting that genus Brachionus dominates plankton species (Pejler 1977; Sharma 1980; Sharma 1983; Sharma 1987). Growth of the planktonic requires water temperature in the range of $13.5^{\circ} \mathrm{C}-32{ }^{\circ} \mathrm{C}$ and variations in the temperature affect the density and diversity of rotifers (Baloch et al. 2008; Gaikwad et al. 2008). Brachionus population during summer was positively correlated with temperature (Patra et al. 2011). Tropical environment favours Brachionidae (Bekleyen 2003; Geng et al. 2005). Preferred pH range (6.5-8.5) of rotifers is key water quality attribute that regulate population growth (Neschuk et al. 2002). Variations in $\mathrm{pH}$ were observed during different months; increase in $\mathrm{pH}$ indicated that density and diversity of rotifers 
changed with the changes in in the $\mathrm{pH}$ either negatively or positively (Thomaz et al. 2007; Sulehria et al. 2009a; Borges and Pedrozo 2009; Dai et al. 2014; Ejaz et al. 2016).

Increase in $\mathrm{pH}$ in monsoon summer and winter seasons may be explained by constant water movements resulting in the changes in free carbon dioxide (Ahmed 2004). $\mathrm{pH}$ contributes significantly in the formation of algal bloom ultimately affecting rotifer diversity and density (Sharma et al. 2013). Physico-chemical parameters vary in different seasons and physicochemical characteristics of water affect the diversity and distribution of rotifers (Chittapun et al. 2007; Sulehria et al. 2009b). Physico-chemical parameters of water affected the abundance and composition of rotifer fauna (Chittapun et al. 2007; Sulehria and Malik 2012).

Dissolved oxygen is a critical factor for the survival of aquatic life (Ejaz et al. 2016) and decline in DO during hot months might result in decreased solubility of oxygen resulting in the lower diversity of rotifers (Sulehria and Malik 2012; Ejaz et al. 2016; Hussain et al. 2016). Rotifers were significantly and positively correlated with algal biomass (Spoljar et al. 2011). Agitation of water due to heavy rainfall, increased day length, enhanced photosynthesis and strong wind may have resulted in high dissolved oxygen content during monsoon (Sharma et al. 2013). Highest conductivity in summer might be due of lower solubility, high temperature and high degradation of organic matter. Rotifers density and diversity have shown correlation with conductivity (Sulehria et al. 2009a, Sulehria and Malik 2012). Increase in the electrical conductivity was reflected by a decrease in the density, the number of rotifer taxa and the Shannon-Wiener index $H^{\prime}$ (Halabowski et al. 2019).

Higher value of species richness in summer were noted, thus, greater planktonic diversity was recorded in summer season whereas low values in winter. Higher values of species diversity were observed in May to August and lower values were recorded from September to April. This may be attributed to the addition of new species and resources during monsoon (Hussain et al. 2016). Similar observations were noted in other studies i.e., higher diversity of partitioning among zooplankton species in combination with the micro- and macro-habitat heterogeneity (Høberg et al. 2002; Segers 2007; Borges and Pedrozo 2009). The highest number of rotifer population was observed in the summer and the lowest in winter. In summer, the highest population of rotifers was that may be credited to food abundance, suitability of the physico-chemical parameters of water and higher reproduction rate. Higher values of species richness are an indication of the presence of larger food chains in the summer season (Adesalu and Nwankwo 2008).

Similar results of diversity indices were observed in fish ponds with Shannon-Wiener Index low in winter and high in summer (Ejaz et al. 2016; Hussain et al. 2016). Greater rotifer diversity and density was observed in the summer season as compared to the winter season (Sulehria et al. 2009b). Seasonal fluctuations in rotifer populations may be attributed to reduced turbidity and high dissolved oxygen during summer and spring (Sharma et al. 2013). Rotifer population increased during spring season is primarily associated with the increase in phytoplankton density. Similar trend in rotifer population during the spring was also reported by Sharma and Sharma (2005), Wanganeo and Wanganeo (2006) and Sharma (2013). Greater diversity at Marala Lake as compared to artificial water bodies and emphasized that natural bodies need to be explored extensively for the biodiversity of rotifers with special reference physiochemical parameters for their conservation and potential use in aquaculture and fisheries. The study emphasized on the conservation of rotifer diversity in order to preserve natural food sources for fish and aquaculture production at commercial level.

Table 1. Physico-chemical parameters (mean $\pm \mathrm{SE}$ ) of water recorded in different seasons from fish ponds of Sialkot, Punjab, Pakistan.

\begin{tabular}{lcccc}
\hline Parameter & Autumn & Winter & Spring & Summer \\
\hline Air Temperature $\left({ }^{\circ} \mathrm{C}\right)$ & $26.5 \pm 0.28 \mathrm{a}$ & $25.6 \pm 0.33 \mathrm{a}$ & $28.3 \pm 0.16 \mathrm{~b}$ & $32.1 \pm 0.16 \mathrm{c}$ \\
Water Temperature $\left({ }^{\circ} \mathrm{C}\right)$ & $24.1 \pm 0.16 \mathrm{~b}$ & $21 \pm 0.28 \mathrm{a}$ & $25.1 \pm 0.16 \mathrm{~b}$ & $32.8 \pm 0.16 \mathrm{c}$ \\
Specific Gravity & $1.002 \pm 0.00$ & $1.003 \pm 0.00$ & $1.001 \pm 0.00$ & $1.001 \pm 0.00$ \\
Dissolved Oxygen $(\mathrm{mg} / \mathrm{L})$ & $8.16 \pm 0.16 \mathrm{~b}$ & $7.16 \pm 0.16 \mathrm{a}$ & $7.83 \pm 0.16 \mathrm{~b}$ & $9.33 \pm 0.16 \mathrm{c}$ \\
Electrical Conductivity $(\mu \mathrm{s} / \mathrm{cm})$ & $369 \pm 2.08 \mathrm{c}$ & $396 \pm 4.58 \mathrm{~d}$ & $345.3 \pm 1.76 \mathrm{~b}$ & $317.3 \pm 3.48 \mathrm{a}$ \\
$\mathrm{pH}$ & $6.76 \pm 0.03 \mathrm{a}$ & $8.56 \pm 0.06 \mathrm{c}$ & $7.16 \pm 0.08 \mathrm{~b}$ & $9.2 \pm 0.05 \mathrm{~d}$ \\
Total Dissolved Solids $(\mathrm{ppm})$ & $179 \pm 2.08 \mathrm{~b}$ & $194.6 \pm 1.45 \mathrm{~d}$ & $184.6 \pm 1.76 \mathrm{c}$ & $160 \pm 2.51 \mathrm{a}$ \\
\hline
\end{tabular}

Mean values with different letters in each row are significantly different from each other at $\mathrm{P} \leq 0.05$, Tukey's Test whereas mean values without letters are statistically non-significant $p>0.05$ 
Table 2. Physico-chemical Parameters (Mean \pm SE) of Water in Different Seasons from Marala Lake (Mean \pm SE) Sialkot, Punjab, Pakistan.

\begin{tabular}{lcccc}
\hline Parameter & Autumn & Winter & Spring & Summer \\
\hline Air Temperature $\left({ }^{\circ} \mathrm{C}\right)$ & $31.8 \pm 0.16 \mathrm{c}$ & $23.1 \pm 0.16 \mathrm{a}$ & $28.1 \pm 0.16 \mathrm{~b}$ & $33.1 \pm 0.16 \mathrm{c}$ \\
Water Temperature $\left({ }^{\circ} \mathrm{C}\right)$ & $27.1 \pm 0.16 \mathrm{c}$ & $19.3 \pm 0.16 \mathrm{a}$ & $25.6 \pm 0.16 \mathrm{~b}$ & $28.1 \pm 0.16 \mathrm{c}$ \\
Specific Gravity & $1.001 \pm 0.00$ & $1.001 \pm 0.00$ & $1.001 \pm 0.00$ & $1.0003 \pm 0.00$ \\
Dissolved Oxygen $(\mathrm{mg} / \mathrm{L})$ & $7.83 \pm 0.16 \mathrm{~b}$ & $7.33 \pm 0.16 \mathrm{a}$ & $8.16 \pm 0.16 \mathrm{~b}$ & $9.66 \pm 0.16 \mathrm{c}$ \\
Electrical Conductivity $(\mu \mathrm{s} / \mathrm{cm})$ & $325.3 \pm 2.02 \mathrm{~d}$ & $259 \pm 0.57 \mathrm{a}$ & $315 \pm 0.57 \mathrm{c}$ & $293 \pm 1.52 \mathrm{~b}$ \\
$\mathrm{pH}$ & $6.5 \pm 0.12 \mathrm{a}$ & $9.06 \pm 0.03 \mathrm{c}$ & $7.2 \pm 0.03 \mathrm{~b}$ & $6.7 \pm 0.05 \mathrm{a}$ \\
Total Dissolved Solids $(\mathrm{ppm})$ & $144 \pm 0.57 \mathrm{~b}$ & $131 \pm 0.57 \mathrm{a}$ & $154.6 \pm 0.33 \mathrm{c}$ & $151.3 \pm 0.66 \mathrm{c}$ \\
\hline Mean values with different letters in each row are significantly different from each other at $\mathrm{p} \leq 0.05$, Tukey's Test whereas mean \\
values without letters are statistically non-significant $\mathrm{p}>0.05$
\end{tabular}

Table 3. Pearson's correlation matrix of Rotifers and Physico-chemical Parameters in Marala Lake from January -December, 2018.

\begin{tabular}{|c|c|c|c|c|c|c|c|c|}
\hline Parameters & $\begin{array}{l}\text { Rotifers } \\
\text { (Ind/L) }\end{array}$ & $\begin{array}{c}\text { Air } \\
\text { Temp. } \\
\left({ }^{\circ} \mathrm{C}\right)\end{array}$ & $\begin{array}{c}\text { Water } \\
\text { Temp. } \\
\left({ }^{\circ} \mathrm{C}\right)\end{array}$ & $\begin{array}{l}\text { Specific } \\
\text { Gravity }\end{array}$ & $\begin{array}{c}\text { Dissolved } \\
\text { Oxygen } \\
(\mathrm{mg} / \mathrm{L})\end{array}$ & $\begin{array}{l}\text { Electrical } \\
\text { Conduc. } \\
(\mu \mathrm{s} / \mathrm{cm})\end{array}$ & pH & $\begin{array}{l}\text { Total } \\
\text { Diss. } \\
\text { Solids } \\
\text { (ppm) }\end{array}$ \\
\hline Rotifers (Ind/L) & 1 & & & & & & & \\
\hline Air Temp. $\left({ }^{\circ} \mathrm{C}\right)$ & $.781^{* *}$ & 1 & & & & & & \\
\hline Water Temp. $\left({ }^{\circ} \mathrm{C}\right)$ & $.810^{* *}$ & $.968^{* *}$ & 1 & & & & & \\
\hline Specific Gravity & $-.754^{* *}$ & $-.743^{* *}$ & $-.712^{* *}$ & 1 & & & & \\
\hline Dissolved Oxygen (mg/L) & $.903^{* *}$ & $.732^{* *}$ & $.711^{* *}$ & $-.641^{*}$ & 1 & & & \\
\hline Electrical Conduc. $(\mu \mathrm{s} / \mathrm{cm})$ & .369 & $.684^{*}$ & $.787^{* *}$ & -.385 & .181 & 1 & & \\
\hline $\mathrm{pH}$ & $-.708^{* *}$ & $-.957^{* *}$ & $-.984^{* *}$ & $-.661^{*}$ & $-.615^{*}$ & $-.856^{* *}$ & 1 & \\
\hline $\begin{array}{l}\text { Total Dissolved Solids (ppm) } \\
{ }^{* *}: \mathrm{p} \leq 0.01,{ }^{*}: \mathrm{p} \leq 0.05,(2 \text {-tail }\end{array}$ & $.821^{* *}$ & $.689^{*}$ & $.828^{* *}$ & $-.617^{*}$ & $.666^{*}$ & $.705^{*}$ & $-.785^{* *}$ & 1 \\
\hline
\end{tabular}

Table 4. Pearson's correlation matrix of Rotifers and Physico-chemical Parameters in Fish Ponds from January December, 2018.

\begin{tabular}{|c|c|c|c|c|c|c|c|c|}
\hline Parameters & $\begin{array}{c}\text { Rotifers } \\
\text { (Ind/L) }\end{array}$ & $\begin{array}{c}\text { Air } \\
\text { Temp. } \\
\left({ }^{\circ} \mathrm{C}\right)\end{array}$ & $\begin{array}{c}\text { Water } \\
\text { Temp. } \\
\left({ }^{\circ} \mathrm{C}\right)\end{array}$ & $\begin{array}{l}\text { Specific } \\
\text { Gravity }\end{array}$ & $\begin{array}{c}\text { Dissolved } \\
\text { Oxygen } \\
(\mathrm{mg} / \mathrm{L})\end{array}$ & $\begin{array}{c}\text { Electrical } \\
\text { Conduc. } \\
(\mu \mathrm{s} / \mathrm{cm})\end{array}$ & pH & $\begin{array}{l}\text { Total } \\
\text { Diss. } \\
\text { Solids } \\
\text { (ppm) }\end{array}$ \\
\hline Rotifers (Ind/L) & 1 & & & & & & & \\
\hline Air Temp. $\left({ }^{\circ} \mathrm{C}\right)$ & $.915^{* *}$ & 1 & & & & & & \\
\hline Water Temp. $\left({ }^{\circ} \mathrm{C}\right)$ & $.936^{* *}$ & $.974^{* *}$ & 1 & & & & & \\
\hline Specific Gravity & $-.810^{* *}$ & $-.795^{* *}$ & $-.776^{* *}$ & 1 & & & & \\
\hline $\begin{array}{l}\text { Dissolved Oxygen } \\
(\mathrm{mg} / \mathrm{L})\end{array}$ & $.892^{* *}$ & $.835^{* *}$ & $.923^{* *}$ & $-.690^{*}$ & 1 & & & \\
\hline $\begin{array}{l}\text { Electrical Conduc. } \\
(\mu \mathrm{s} / \mathrm{cm})\end{array}$ & $-.902^{* *}$ & $-.924^{* *}$ & $-.935^{* *}$ & $-.926^{* *}$ & $-.869^{* *}$ & 1 & & \\
\hline $\mathrm{pH}$ & .278 & .530 & .476 & .038 & .322 & -.263 & 1 & \\
\hline $\begin{array}{l}\text { Total Dissolved Solids } \\
(\mathrm{ppm}) \\
{ }^{* *}: \mathrm{p} \leq 0.01,^{*}: \mathrm{p} \leq 0.05\end{array}$ & $\begin{array}{l}-.942^{* *} \\
\text { tailed). }\end{array}$ & $-.888^{* *}$ & $-.941^{* *}$ & $-.690^{*}$ & $-.919^{* *}$ & $-.854^{* *}$ & -.364 & 1 \\
\hline
\end{tabular}


Table 5. ANOVA for Physico-chemical Parameters recorded during from different sites (Fish Ponds and Marala Lake) from January-December, 2018.

\begin{tabular}{|c|c|c|c|c|c|c|}
\hline Parameters & Source & DF & SS & MS & $\mathbf{F}$ & $\mathbf{P}$ \\
\hline \multirow{4}{*}{ Air Temperature } & Seasons & 3 & 206.075 & 68.6917 & 7797.43 & 0.0000 \\
\hline & Sites & 1 & 4.167 & 4.1667 & 472.97 & 0.0000 \\
\hline & Season* Site & 3 & 46.87 & 15.6233 & 1773.46 & 0.0000 \\
\hline & Error & 14 & 0.123 & 0.0088 & & \\
\hline \multirow{4}{*}{ Dissolved Oxygen } & Seasons & 3 & 16.2167 & 5.40558 & 923.75 & 0.0000 \\
\hline & Site & 1 & 0.033 & 0.033 & 5.64 & 0.0324 \\
\hline & Season ${ }^{*}$ Site & 3 & 0.491 & 0.16367 & 27.97 & 0.0000 \\
\hline & Error & 14 & 0.0819 & 0.00585 & & \\
\hline \multirow{4}{*}{ Electrical Conductivity } & Seasons & 3 & 5471.8 & 1823.9 & 154.76 & 0.0000 \\
\hline & Site & 1 & 20010.4 & 20010.4 & 1697.85 & 0.0000 \\
\hline & Season* Site & 3 & 10610.5 & 3536.8 & 300.09 & 0.0000 \\
\hline & Error & 14 & 165 & 11.8 & & \\
\hline \multirow{4}{*}{ Specific Gravity } & Seasons & 3 & $1.79 \times 10^{-06}$ & $5.972 \times 10^{-07}$ & 6.69 & 0.0050 \\
\hline & Site & 1 & $4.17 \times 10^{-08}$ & $4.167 \times 10^{-08}$ & 0.47 & 0.5057 \\
\hline & Season ${ }^{*}$ Site & 3 & $7.92 \times 10^{-07}$ & $2.639 \times 10^{-07}$ & 2.96 & 0.0689 \\
\hline & Error & 14 & $1.25 \times 10^{-06}$ & $8.929 \times 10^{-08}$ & & \\
\hline \multirow{4}{*}{ Total Dissolved Solids } & Seasons & 3 & 407.46 & 135.82 & 20.5 & 0.0000 \\
\hline & Site & 1 & 5797.04 & 5797.04 & 875.03 & 0.0000 \\
\hline & Season* Site & 3 & 1597.12 & 532.37 & 80.36 & 0.0000 \\
\hline & Error & 14 & 92.75 & 6.62 & & \\
\hline \multirow{4}{*}{ Water Temperature } & Seasons & 3 & 298.615 & 99.5382 & 5668.62 & 0.0000 \\
\hline & Site & 1 & 2.6 & 2.6004 & 148.09 & 0.0000 \\
\hline & Season ${ }^{*}$ Site & 3 & 40.108 & 13.3693 & 761.37 & 0.0000 \\
\hline & Error & 14 & 0.246 & 0.0176 & & \\
\hline \multirow{4}{*}{ pH } & Seasons & 3 & 15.5422 & 5.18074 & 1682.84 & 0.0000 \\
\hline & Site & 1 & 1.804 & 1.80402 & 585.99 & 0.0000 \\
\hline & Season ${ }^{*}$ Site & 3 & 7.5685 & 2.52285 & 819.49 & 0.0000 \\
\hline & Error & 14 & 0.0431 & 0.00308 & & \\
\hline
\end{tabular}

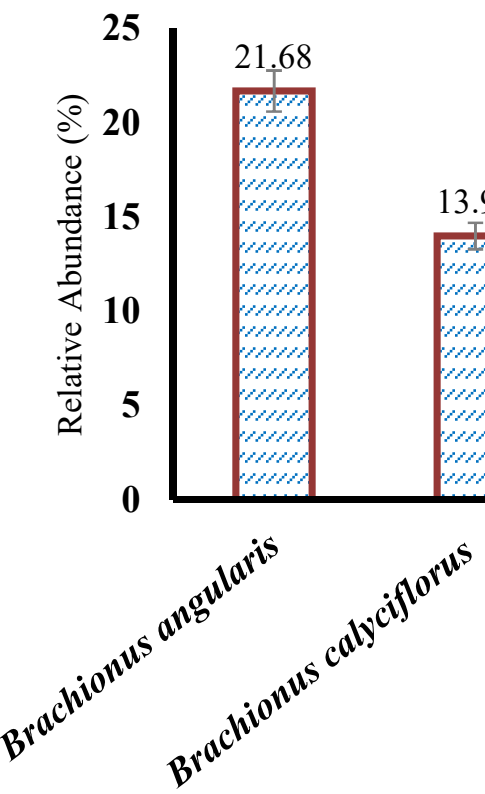

Figure 2. Overall relative abundance (\%) of rotifer species in fish ponds of Sialkot, Punjab, Pakistan during 2017-18. 


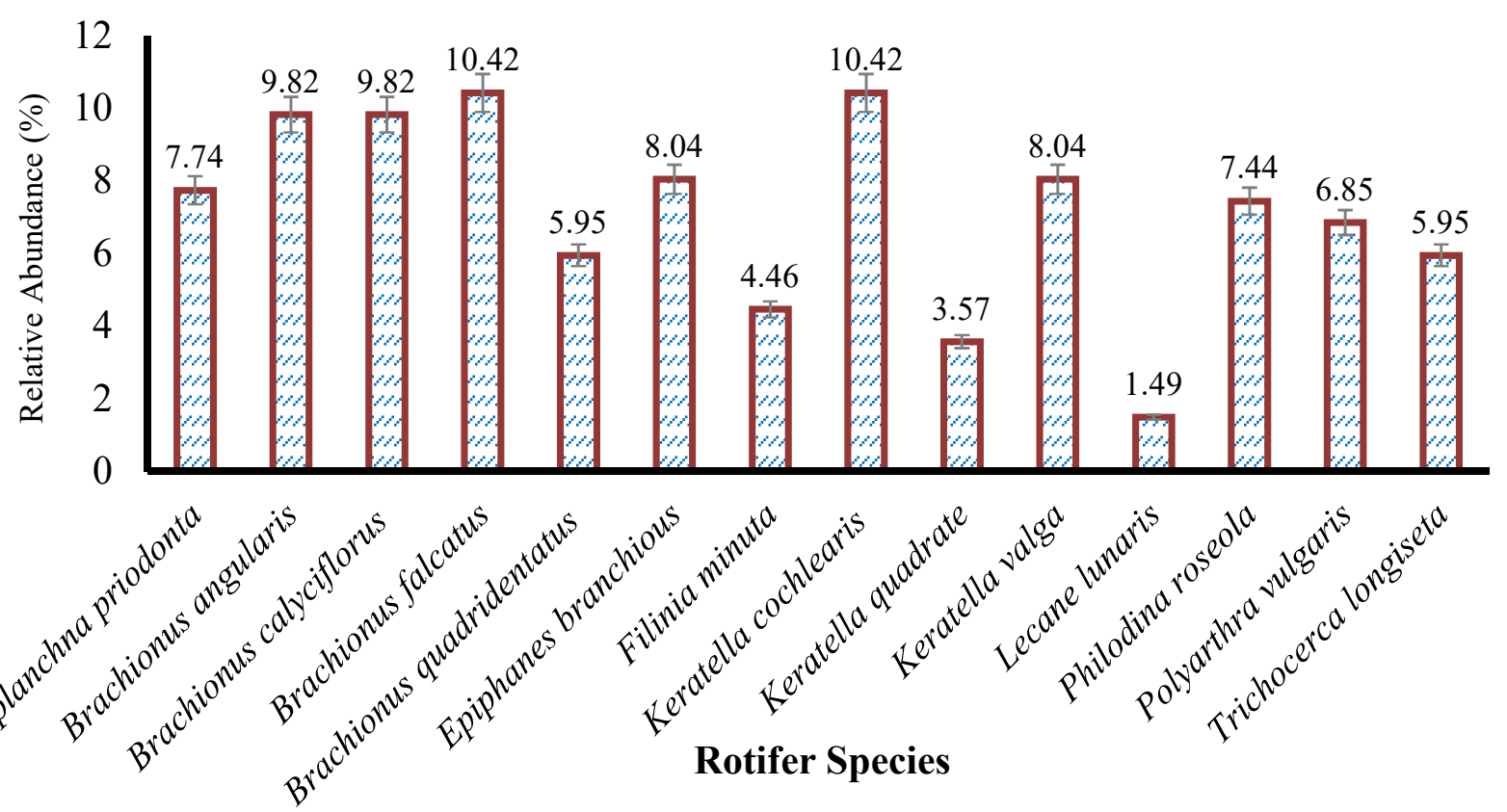

Figure 3. Overall relative abundance (\%) of rotifer species during 2017-18 in Marala Headwork Sialkot, Punjab, Pakistan.

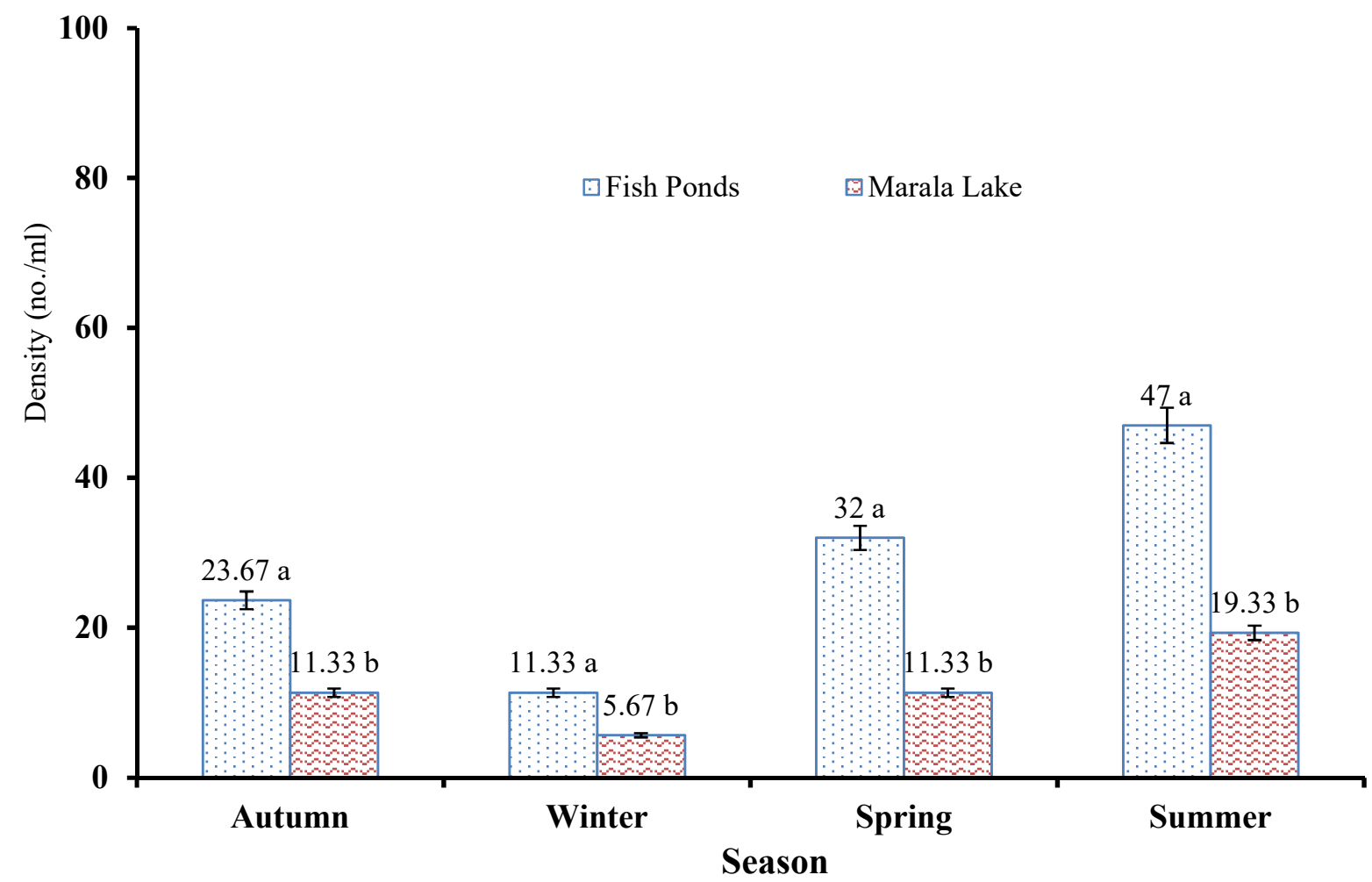

Figure 4. Density (individual/ml) of rotifer collected during different seasons from fish ponds and Marala Headwork Sialkot, Punjab, Pakistan during 2017-18. 
Table 6. Diversity indices of rotifers collected from fish ponds of Sialkot, Punjab, Pakistan during 2017-2018.

\begin{tabular}{lcccccc}
\hline Season & $\begin{array}{c}\text { Shannon-Wiener } \\
\text { index (H) }\end{array}$ & $\begin{array}{c}\text { Simpson index of } \\
\text { dominance (D) }\end{array}$ & $\begin{array}{c}\text { Simpson index } \\
\text { of diversity } \\
\text { (SID) }\end{array}$ & $\begin{array}{c}\text { Simpson } \\
\text { reciprocal } \\
\text { index } \\
\text { (SRI) }\end{array}$ & $\begin{array}{c}\text { Species } \\
\text { richness } \\
\text { (SR) }\end{array}$ & $\begin{array}{c}\text { Species } \\
\text { evenness } \\
\text { (SE) }\end{array}$ \\
\hline Autumn & 1.902 & & & 7.692 & 3.918 \\
Winter & 1.611 & 0.13 & 0.87 & 5.682 & 4.064 \\
Spring & 1.902 & 0.176 & 0.87 & 7.692 & 3.918 \\
Summer & 1.915 & 0.137 & 0.863 & 7.299 & 3.402 \\
\hline
\end{tabular}

Table 7. Diversity indices of rotifers collected from Marala Lake of Sialkot, Punjab, Pakistan during 2017-2018

\begin{tabular}{|c|c|c|c|c|c|c|}
\hline Season & $\begin{array}{c}\text { Shannon- } \\
\text { Wiener index } \\
\text { (H) }\end{array}$ & $\begin{array}{c}\text { Simpson } \\
\text { index of } \\
\text { dominance } \\
\text { (D) }\end{array}$ & $\begin{array}{l}\text { Simpson } \\
\text { index of } \\
\text { diversity } \\
\text { (SID) }\end{array}$ & $\begin{array}{c}\text { Simpson } \\
\text { reciprocal } \\
\text { index (SRI) }\end{array}$ & $\begin{array}{c}\text { Species } \\
\text { richness (SR) }\end{array}$ & $\begin{array}{c}\text { Species } \\
\text { evenness (SE) }\end{array}$ \\
\hline Autumn & 2.46 & 0.080 & 0.920 & 12.50 & 06.48 & 0.96 \\
\hline Winter & 2.01 & 0.135 & 0.865 & 07.41 & 04.83 & 0.92 \\
\hline Spring & 2.50 & 0.077 & 0.923 & 12.98 & 06.05 & 0.98 \\
\hline Summer & 2.52 & 0.076 & 0.924 & 13.16 & 05.58 & 0.98 \\
\hline
\end{tabular}

Conclusion: Rotifer diversity recorded fourteen species and 09 genera belonging to 06 families at Marala Lake whereas in fish ponds 07 species representing 05 genera and 04 families were observed. Brachionidae was the most prevalent family throughout the year at both habitat types. Greater rotifer diversity was recorded in the summer as compared to other seasons at both habitats. Greater diversity of rotifers in fish ponds can act as a valuable resource for the conservation of freshwater biodiversity and improve aquaculture.

\section{REFERENCES}

Adesalu, T. and D. Nwankwo (2008). Effect of water quality indices on phytoplankton of a sluggish tidal creek in Lagos, Nigeria. Pakistan J. Biol. Sci. 11: 836-844.

Allen, M., J. Vandyke and C. Cáceres (2011). Metacommunity assembly and sorting in newly formed lake communities. Ecology. 92: 269-275.

Ahmed, A. (2004). Ecological studies of the river Padma at Mawa Ghat, Munshiganj. Pakistan J. Biol. Sci. 7: 1865-1869.

APHA (2005). Standard methods for the examination of water and wastewater, $21^{\text {st }}$ edn. American Water Works Association and Water Environment Federation, Washington.

Baloch, W., A. Soomro and G. Buledi (2008). Zooplankton, especially Rotifer and Cladoceran Communities of the spring and rainwater streams Nai) in Kirthar range, Sindh,
Pakistan. Sindh Univ. Res. J. (Sci. Ser.). 40: 17-22.

Baloch, W., A. Soomro and S. Jafri (2004). Zooplankton of a highly saline water body, near Hyderabad, Sindh [Pakistan]. Sindh Univ. Res. J. (Sci. Ser.). 36: 25-28.

Baloch, W., S. Jafri and A. Soomro (2005). Spring zooplankton composition of Rawal lake, Islamabad. Sindh Univ. Res. J. (Sci. Ser.). 37: 41-46.

Barnes, R. S. K., P. P. Calow, P. J. Olive, D. W. Golding and J. I. Spicer, 2009: The invertebrates: a synthesis. John Wiley \& Sons.

Bekleyen, A., 2003. A taxonomical study on the zooplankton of Goksu Dam Lake (Diyarbakir). Turk. J. Zool. 27: 95-100.

Bhandarkar, S. V. (2015). Species Diversity of Rotifers in Lentic Ecosystem of Dhukeshwari Temple Pond Deori with Reference to Cultural Eutrophication. Int. J. Curr. Microbiol. App. Sci. 4: 736-743.

Borges, M. and C. Pedrozo (2009). Zooplankton (Cladocera, Copepoda and Rotifera) richness, diversity and abundance variations in the Jacuí Delta, RS, Brazil, in response to the fluviometric level. Acta Limnol. Bras. 21:101110.

Chieng, C. C. Y., H. M. Daud, F. M. Yusoff and M. Abdullah (2018). Immunity, feed, and husbandry in fish health management of cultured Epinephelus fuscoguttatus with reference to Epinephelus coioides. Aquacult. and fisheries. 3: 51-61. 
Chittapun, S., P. Pholpunthin and H. Segers (2007). Diversity of rotifer fauna from five coastal peat swamps on Phuket Island, Southern Thailand. ScienceAsia. 33: 383-387.

Cottenie, K. and L.D. Meester (2004). Metacommunity structure: synergy of biotic interactions as selective agents and dispersal as fuel. Ecology. 85: 114-119.

Dai, L.L., Y.C. Gong, X.M. Li, W.S. Feng and Y.H. Yu (2014). Influence of environmental factors on zooplankton assemblages in Bosten Lake, a large oligosaline lake in arid northwestern China. ScienceAsia. 40: 1-10.

Dhanasekaran, M., P. S. Bhavan, N. Manickam and R. Kalpana (2017). Physico-chemical characteristics and zooplankton diversity in a perennial lake at Dharmapuri (Tamil Nadu, India). J. Entomol. Zool. Stud. 5: 285-292.

Ejaz, M., A. Q. K. Sulehria, A. Maqbool, A. Hussain and M. Yousaf (2016). Density and diversity of planktonic rotifers in Nandipur Canal. Biologia (Pakistan). 62: 9-18.

Ekhande, A., J. Patil, R. Patil and G. Padate (2013). Water quality monitoring-study of seasonal variation of rotifers and their correlation with physicochemical parameters of Yashwant Lake, Toranmal (MS) India. Arch. Appl. Sci. Res. 5: 177-181.

Gaikwad, S., K. Ingle and S. Thorat (2008). Study of zooplankton emergence pattern and resting egg diversity of recently dried waterbodies in North Maharashtra Region. J. Environ. Biol. 29(3): 353-356.

Geng, H., P. Xie, D. Deng and Q. Zhou (2005). The rotifer assemblage in a shallow, eutrophic Chinese lake and its relationships with Cyanobacterial blooms and Crustacean zooplankton. J. Freshw. Ecol. 20(1), 93- 100.

Gunwati, V. A. and S. S. Mokashe (2014). Study on Diversity of Rotifer from water Bodies around Aurangabad region. Int. Res. J. Biol. Sci. 3: 30-33.

Halabowski, D., I. Bielańska-Grajner and I. Lewin (2019). Effect of underground salty mine water on the rotifer communities in the Bolina River (Upper Silesia, Southern Poland). Knowl. Manag. Aquat. Ecosyst.(420), 31: 1-9

Høberg, P., M. Lindholm, L. Ramberg and D. Hessen (2002). Aquatic food web dynamics on a floodplain in the Okavango Delta, Botswana. Hydrobiologia, 470: 23-30.

Hussain, A., A. Q. K. Sulehria, M. Ejaz and A. Maqbool (2016). Population Dynamics of Rotifers in the Floodplain of River Ravi, Pakistan. Pakistan J. Zoo. 48: 215-225.
Kar, S. and D. Kar (2016). Zooplankton diversity of a freshwater wetland of Assam. Int. J. Adv. Biotechnol. Res. 7: 614-620.

Kirk, K. L. (1997). Life-history responses to variable environments: starvation and reproduction in planktonic rotifers. Ecology. 78, 434-441

Kumar, K. H. and B. Kiran (2015). Population dynamics of Rotifers in Jannapura tank, Karnataka. Int. J. Fish. Aquat. Stud. 3(1): 165-168

Lubzens, E., O. Zmora and Y. Barr (2001). Biotechnology and aquaculture of rotifers. Rotifera IX. Springer.

Mahar, M., W. Baloch and S. Jafri (2000). Diversity and seasonal occurrence of planktonic rotifers in Manchar Lake, Sindh, Pakistan. Pakistan J. Zoo. 1(1): 25-32.

Malik, M. and A. Sulehria (2004). Seasonal variation, density and diversity of planktonic rotifers in the river Ravi [Pakistan]. Biologia (Pakistan). 50: $5-17$

Neschuk, N., M. Claps and N. Gabellone (2002). Planktonic rotifers of a saline-lowland river: the Salado River (Argentina). in Proceedings of the Annales de Limnologie-Int. J. Limnology. 191-198 pp

Neves, I., O. Rocha, K. Roche and A. Pinto (2003). Zooplankton community structure of two marginal lakes of the river Cuiabá (Mato Grosso, Brazil) with analysis of Rotifera and Cladocera diversity. Braz. J. Biol. 63: 329343.

Papa, R. D. S. and M. T. Zafaralla (2011). The Composition, Diversity and Community Dynamics of Limnetic Zooplankton in a Tropical Caldera Lake (Lake taal, Philippines). Raffles B. Zool. 59 (1): 1-7.

Patra, A., K.B. Santra, and C.K. Manna (2011). Ecology and diversity of zooplankton in relation to physico-chemical characteristics of water of Santragachi Jheel, West Bengal, India. Wetl. Ecol. Manag. 5: 20-39

Pejler, B. (1977). On the global distribution of the family Brachionidae (Rotatoria). Arch. Hydrobiol. Suppl. 53: 255-306.

Pennak, R. W. (1989). Fresh-water invertebrates of the United States. Protozoa to Mollusca. 3rd edition, xvi. New York. 628p

Rajendiran, A. and P. Subramanian (2007). Mass production of freshwater rotifer, Brachionus calyciflorus, under different diets and regimes. J. Applied Aquaculture. 19:101-111.

Saler, S. (2009). Rotifers of kepektas dam lake (ElazigTurkey). Iran J. Sci. Technol. (Sci.). 33: 121126. 
Saler, S. and D. Sen (2002). Seasonal variation of Rotifera Fauna of cip dam lake (ElazigTurkey). Pakistan J. Biol. Sci. 5: 1274-1276.

Schober, P., C. Boer and L. Schwarte (2018). Correlation Coefficients: Appropriate Use and Interpretation. Anesth. Analg. 126(5):17631768

Segers, H. (2007). Annotated checklist of the rotifers (Phylum Rotifera), with notes on nomenclature, taxonomy and distribution. Zootaxa. 1564: 1-104.

Shannon, C. E. and W. Weaver (1949).The mathematical theory of communication (Urbana, IL. University of illinois Press IL.

Sharma, B. (1980). A new lecanid rotifer from West Bengal, India. Bangladesh J. Zool. 8: 131-132.

Sharma, B. (1983). The Indian species of the genus Brachionus (Eurotatoria: Monogononta: Brachionidae). Biology of Rotifers. Springer.

Sharma, B. (1987). Indian brachionidae (Eurotatoria: Monogononta) and their distribution. Hydrobiologia. 144: 269-275.

Sharma, B. (2000). Rotifers from some tropical floodplain lakes of Assam (NE India). Trop Ecol. 41:175-182.

Sharma, B.K. and S. Sharma (2005). Faunal diversity of rotifers (Rotifera: Eurotatoria) of Deepor Beel, Assam (Northeast India) - A Ramsar site. J. Bombay Nat. Hist. Soc. 102(2):169-175.

Sharma, K.K., R. Sharma, S. Langer, Chandrakiran (2013). Diversity and Density Variations in the Community Structure of Rotifera Fauna of Behlol Nullah, Jammu (J\&K), India. Asian Academic Research J. Multidisciplinary. 1(14): 129-144

Sharma, R. (2013). Biomonitoring of Behlol Nullah (a tributary of river Tawi) in Jammu. Ph.D. Thesis, University of Jammu, Jammu.

Simpson, E. (1949). Measurement of diversity. Nature, 163: 688. Simpson688163Nature1949.

Skowronek, E., A. Cudak and I. Bielańska-Grajner (2012). Effect of recreation on the species richness and diversity of rotifers in ponds. J. Water Res. Prot. 4: 795-799.

Spoljar, M., T. Tomljanovic and I. Lalic (2011). Eutrophication impact on zooplankton community: A shallow lake approach. Holistic Approach Environ. 14:131-142.
Sugumaran, J. and A. Amsath (2015). Seasonal Diversity of Rotifers from Agniyar Estuary, Thanjavur District, Tamil Nadu, India. Int. J. Pure Appl. Zool. 3: 287-292.

Sulehria, A. Q. K. and M. A. Malik (2012). Population dynamics of planktonic rotifers in Balloki Headworks. Pakistan J. Zoo. 44: 663-669.

Sulehria, A. Q. K., M. F. Qamar, R. Anjum, M. Ejaz and A. Hussain (2009a). Seasonal fluctuations of Rotifers in a fish pond at District Bahawalnagar, Pakistan. Biologia (Pakistan). 55: 21-28.

Sulehria, A.Q.K., M. F. Qamar, S. Haider, M. Ejaz and A. Hussain. (2009b). Water quality and Rotifer diversity in the fish pond at district Mianwali, Pakistan. Biologia (Pakistan). 55(1\&2): 79-85.

Thomaz, S. M., L. M. Bini and R. L. Bozelli (2007). Floods increase similarity among aquatic habitats in river-floodplain systems. Hydrobiologia. 579: 1-13.

Vázquez-Sánchez, A., G. Reyes-Vanegas, S. Nandini and S.S.S. Sarma (2014). Diversity and abundance of rotifers during an annual cycle in the reservoir Valerio Trujano (Tepecoacuilco, Guerrero, Mexico). Inland Waters. 4(3):293302.

Wallace, R. and H. Smith (2013). Rotifera. eLS. Wiley, Chichester. https://doi. org/10.1002/9780470015902. a0001588. pub2.

Wallace, R. L., T. W. Snell, C. Ricci and N. Thomas (2006). Rotifera. 1, Biology, Ecology and Systematics. Backhuys Publishers.

Wanganeo, A. and R. Wanganeo (2006). Variation in zooplankton population in two morphologically dissimilar rural lakes of Kashmir Himalyas. Proc. Natl. Acad. Sci. India. 76(3): 222-239.

Ward, H. and G. Whipple (1959). Fresh Water Biology, 2nd Edn „John Wiley and Sons. New York, USA.

Yoshinaga, T., A. Hagiwara and K. Tsukamoto (2003). Life history response and age-specific tolerance to starvation in Brachionus plicatilis of Muller (Rotifera). J. Exp. Mar. Biol. Ecol. 287: 261-271.

Zahid, M. and G. Rasul (2011). Thermal classification of Pakistan. Atmospheric and Climate Sciences. 19:1(4):206-13. 